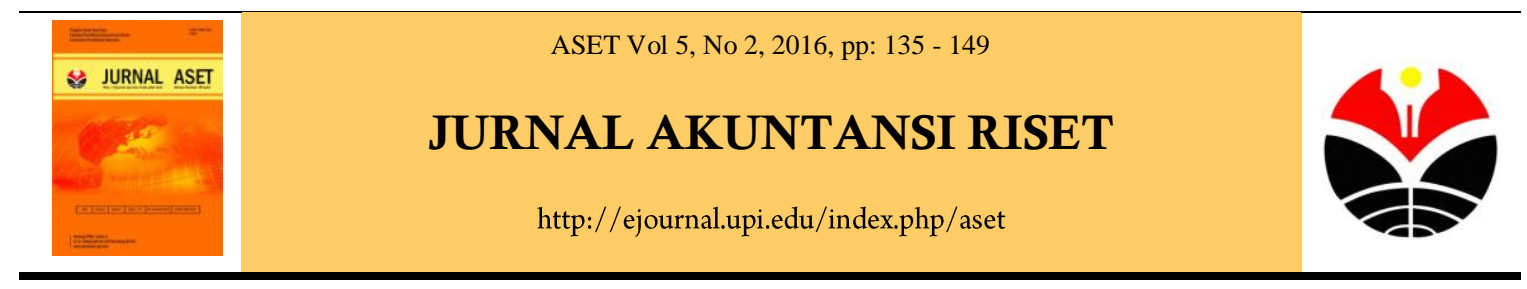

\title{
APLIKASI PENJUALAN TUNAI HARIAN KEBUTUHAN PANGAN PADA KKB PT.DIRGANTARA INDONESIA “WAHANA RAHARJA"
}

Junaedi Abdillah ${ }^{1}$

STMIK \& Politeknik LPKIA. Bandung

Eti Suprihatin ${ }^{2}$

STMIK \& Politeknik LPKIA. Bandung

\section{Info Artikel Abstrak}

Diterima : 18-08-2016 Pokok bahasan dalam penelitian ini dititik beratkan pada sistem informasi akuntansi

Direvisi : 29-08-2016 penjualan tunai harian atas kebutuhan pangan yang diterapkan di bagian penjualan

Diterbitkan : 18-09-2016 tunai Koperasi Keluarga Besar PT. Dirgantara Indonesia "Wahana Raharja". Pada bagian penjualan tunai harian ini ada beberapa kendala yang dihadapi oleh pengelola penjualan tunai harian seperti, proses transaksi penjualan masih dilakukan secara

Keywords: manual, sehingga diperlukan aplikasi yang mampu mendukung pengambilan

Aplikasi, Penjualan Tunai. $\quad$ keputusan dalam memperoleh informasi penjualan yang optimal. Berdasarkan analisis dari kendala yang ada di bagian penjualan tunai harian Koperasi Keluarga Besar PT. Dirgantara Indonesia "Wahana Raharja" penulis mengusulkan akan membangun aplikasi berbasis database menggunakan Microsoft Access 2013 dengan judul "APLIKASI PENJUALAN TUNAI HARIAN KEBUTUHAN PANGAN PADA KKB PT. DIRGANTARA INDONESIA - WAHANA RAHARJA” yang dapat menangani seluruh data transaksi yang akan ditangani menjadi laporan penjualan secara cepat dan tepat, serta akan dirancang dokumen yang dapat menampilkan data barang, data penjualan, data pelanggan, dan merancang laporan yang dapat menampilkan laporan penjualan secara akurat dan tepat sehingga dapat memudahkan pengambilan keputusan bagi pihak yang terkait. Metode penelitian yang digunakan adalah metode waterfall yaitu melakukan pendekatan secara sistematis dan urut mulai dari level kebutuhan system lalu menuju ke tahap analisis, desain, codingtesting/verification, dan maintenance. Disebut dengan waterfall karena tahap demi tahap yang dilalui harus menunggu selesainya tahap sebelumnya dan berjalan berurutan

(C) Jurnal Akuntansi Riset. Program Studi Akuntansi. FPEB. UPI

\footnotetext{
Alamat korespondensi :

${ }^{1}$ Program Studi Komputerisasi Akuntansi STMIK \& Politeknik LPKIA Bandung

E-mail (junaedizalfa@gmail.com)

${ }^{2}$ Program Studi Komputerisasi Akuntansi STMIK \& Politeknik LPKIA Bandung

E-mail (ettysumadi@yahoo.com)
} 


\section{PENDAHULUAN}

Koperasi Keluarga Besar PT Dirgantara Indonesia "Wahana Raharja” adalah badan usaha yang beranggotakan para pegawai dari PT Dirgantara Indonesia baik tetap maupun outsourcing yang sudah terdaftar dan memenuhi syarat keanggotakan. Koperasi Keluarga Besar PT Dirgantara Indonesia "Wahana Raharja” memiliki unit usaha penjualan tunai yang bertujuan untuk meningkatkan kesejahteraan dan memperoleh laba juga menjaga kesinambungan koperasi di masa yang akan datang.

Dalam operasionalnya koperasi "Wahana Raharja" dikelola oleh para pegawai PT Dirgantara Indonesia yang pelaksanaan pengimputan data penjualan tunai koperasinya dilakukan setelah pulang kerja lapangan. Sistem administrasi penjualan tunai yang berjalan masih dilakukan secara manual. Proses manual tersebut membutuhkan waktu input yang lama dan tidak efisien serta tempat penyimpanan yang kurang baik rentan akan human error. Selain itu keamanan data juga kurang baik karena setiap orang dapat melakukan proses data.

Bagi pengelola Koperasi Keluarga Besar PT Dirgantara Indonesia "Wahana Raharja”, dengan System akuntansi penjualan tunai terkomputerisasi dapat melakukan pemprosesan dan pengelolaan data yang telah dimasukan dengan lebih cepat, tingkat kesalahan input dan perhitungan lebih rendah, dapat dilakukan penyimpanan data dan pembuatan laporan penjualan tunai. Sehingga diharapkan dapat menyediakan informasi relevan, akurat yang dapat digunakan untuk kepentingan koperasi. Dengan demikian prodesur yang tidak efektif dan efisien pun dapat dihilangkan. Untuk itu dalam operasional Koperasi Keluarga Besar PT Dirgantara Indonesia "Wahana Raharja" untuk system akuntansi penjualan tunai terkomputerisasi sangat diperlukan, oleh karenanya perlu dibuat suatu aplikasi yang dapat memaksimalkan system penjualan tunai yaitu "Aplikasi Penjualan Tunai Harian Kebutuhan Pangan Berbasis Komputer pada Koperasi Keluarga Besar PT. Dirgantara Indonesia "Wahana Raharja”" yang digunakan untuk pembuatan proyek akhir. Diharapkan Aplikasi yang akan dibuat dapat membantu dalam meningkatkan kinerja manajerial pengelola Koperasi Keluarga Besar PT. Dirgantara Indonesia "Wahana Raharja" pada unit usaha penjualan tunai sehingga dapat memajukan usaha Koperasi Keluarga Besar PT Dirgantara Indonesia "Wahana Raharja”

\section{KAJIAN LITERATUR}

Pengertian sistem informasi akuntansi menurut Krismiaji (2010), Sistem informasi akuntansi adalah sebuah sistem yang memproses data dan transaksi guna menghasilkan informasi yang bermanfaat untuk merencanakan, mengendalikan dan mengoperasikan bisnis. La Midjan dan Azhar Susanto (1995), Sistem Informasi Akuntansi merupakan suatu sistem pengolahan data akuntansi yang terdiri dari koordinasi manusia, alat dan metode berinteraksi dalam suatu wadah organisasi yang terstruktur untuk menghasilkan informasi akuntansi keuangan dan informasi akuntansi managemen yang terstruktur, serta James A. Hall (2001), AIS subsistems process financial transactions and nonfinancial transactions, that directly affect the processing of financial transactions.

Berdasarkan tiga pendapat tersebut dapat ditarik kesimpulan bahwa sistem informasi akuntansi merupakan kegiatan yang memproses data dari transaski keuangan melalui 
koordinasi manusia, alat, dan metode yang dapat menghasilkan informasi keuangan bagi perusahaan.

Sigit Hermawan dan Masyhad (2006), penjualan adalah aliran kas masuk atau aktiva lain yang timbul karena perusahaan menjual barang dagangan. Secara umum penjualan sama artinya dengan pendapatan pada perusahaan jasa. Penjualan barang dagangan terjadi ketika perusahaan melakukan proses penjualan kepada pihak lain. Penjualan dapat dilakukan dengan tunai dan kredit. Penjualan barang dagangan tersebut diakui sebagai pendapatan oleh perusahaan.

James M. Reeve dkk (2009), penjualan adalah total jumlah yang dibebankan pada pelanggan atas barang terjual, baik penjualan kas maupun kredit. Baik retur dan potongan penjualan, maupun diskon penjualan dikurangkan dari penjualan untuk menghasilkan penjualan bersih. Harga pokok penjualan atau harga pokok barang yang terjual, adalah biaya barang yang terjual ke pelanggan.

Mulyadi (2008), Penjualan adalah kegiatan penjualan yang terdiri dari transaksi penjualan barang atau jasa, baik secara kredit maupun secara tunai.

Dapat disimpulkan bahwa penjualan merupakan kegiatan yang dilakukan perusahaan menyerahkan barang atau jasa kepada pelanggan baik secara tunai maupun kredit selanjutnya menerima sejumlah uang atau hak untuk menagih atas terjadinya penjualan tersebut.

Puspitawati \& Anggadini (2011), Flowmap merupakan diagram alir yang menunjukkan arus dokumen, aliran data fisik, entitas sistem informasi, dan kegiatan operasi yang digunakan dengan sistem informasi. Terdapat dua jenis entitas:

1. Entitas dalam (Internal): Pelaku proses, yaitu personal, tempat bagian, atau mesin seperti komputer dalam suatu sistem yang melakukan kegiatan memproses/mengolah (transformasi) data atau kegiatan proses informasi.

2. Entitas Luar (External): Entitas atau satuan unit yang terletak di lingkungan/di luar sistem yang mengirim data ke sistem tersebut atau menerima data dari sistem tersebut. 


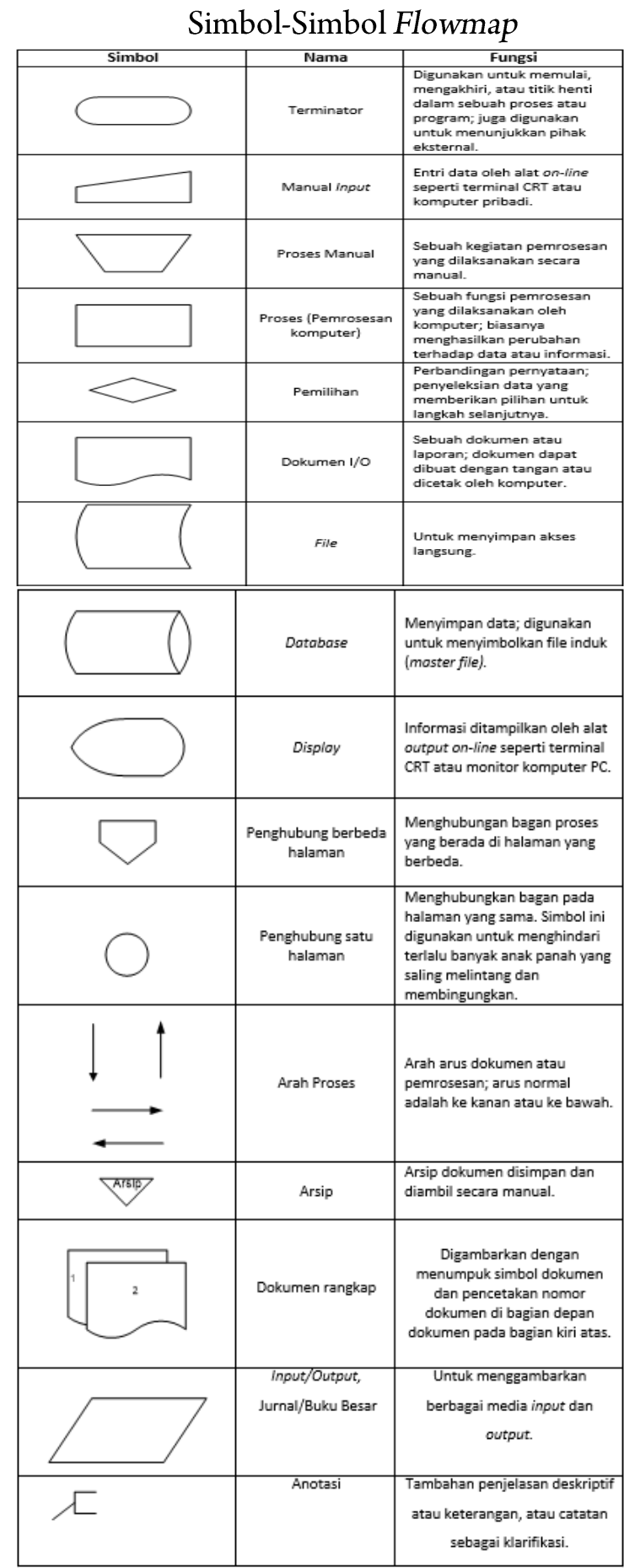

Andri Kristanto (2008) :

1. Diagram Konteks (Context Diagram) adalah sebuah diagram sederhana yang menggambarkan hubungan antara entiti luar, masukan, dan keluaran dari sistem. 
2. DFD (Data Flow Diagram) adalah suatu model logika data atau proses yang dibuat untuk menggambarkan darimana asal data dan ke mana tujuan data yang keluar dari sistem, di mana data disimpan, proses apa yang menghasilkan data tersebut dan interaksi antara data yang tersimpan dan proses yang dikenakan pada data tersebut

\section{Simbol-Simbol DFD}

\begin{tabular}{|c|c|c|}
\hline \multicolumn{1}{|c|}{ Simbol } & Nama & Penjelasan \\
\hline & $\begin{array}{c}\text { Sumber dan tujuan } \\
\text { data }\end{array}$ & $\begin{array}{c}\text { Karyawan dan organisasi yang } \\
\text { mengirim data ke dan menerima } \\
\text { data dari sistem digambarkan } \\
\text { dengan kotak }\end{array}$ \\
\hline & Arus data & $\begin{array}{c}\text { Arus data yang masuk ke dalam dan } \\
\text { ke luar dari sebuah proses } \\
\text { digambarkan dengan anak panah }\end{array}$ \\
\hline & Proses transformasi & $\begin{array}{c}\text { Proses yang mengubah data dari } \\
\text { input menjadi output digambarkan } \\
\text { dengan lingkaran }\end{array}$ \\
\hline & Penyimpanan data & $\begin{array}{c}\text { Penyimpanan data digambarkan } \\
\text { dengan dua garis horizontal (paralel) }\end{array}$ \\
\hline
\end{tabular}

K. and A. Koniyo (2007), ERD merupakan notasi grafis dalam pemodelan data konseptual yang mendeskripsikan hubungan antarpenyimpanan. ERD digunakan untuk memodelkan struktur data dan hubungan antardata, karena hal ini relatif kompleks. Dengan ERD kita dapat menguji model dengan mengabaikan proses yang harus dilakukan. ERD menggunakan sejumlah notasi dan simbol untuk menggambarkan struktur dan hubungan antardata. Pada dasarnya ada 3 macam simbol yang digunakan, yaitu entity, atribut, dan relationship.

Entity adalah suatu objek yang dapat diidentifikasi dalam lingkungan pemakai, sesuatu yang penting bagi pemakai dalam konteks sistem yang akan dibuat. Entitas digambarkan dalam bentuk persegi empat.

Atribut. Entitas mempunyai elemen yang disebut atribut dan berfungsi mendeskripsikan karakter entitas, misalnya atribut nama barang dari entitas barang. Setiap ERD bisa berisi lebih dari satu atribut. Entitas digambarkan dalam bentuk elips.

Hubungan - relationship. Sebagaimana halnya entitas, hubungan pun harus dibedakan antara hubungan atau bentuk hubungan antarentitas dengan isi dari hubungan itu sendiri. Misalnya dalam kasus hubungan antara entitas barang dan entitas pelanggan adalah menjual barang, sedangkan isi hubungannya dapat berupa tanggal jual atau yang lainnya. Relationship digambarkan dalam bentuk intan (diamonds).

\section{Simbol entity, atribut, dan relationship}




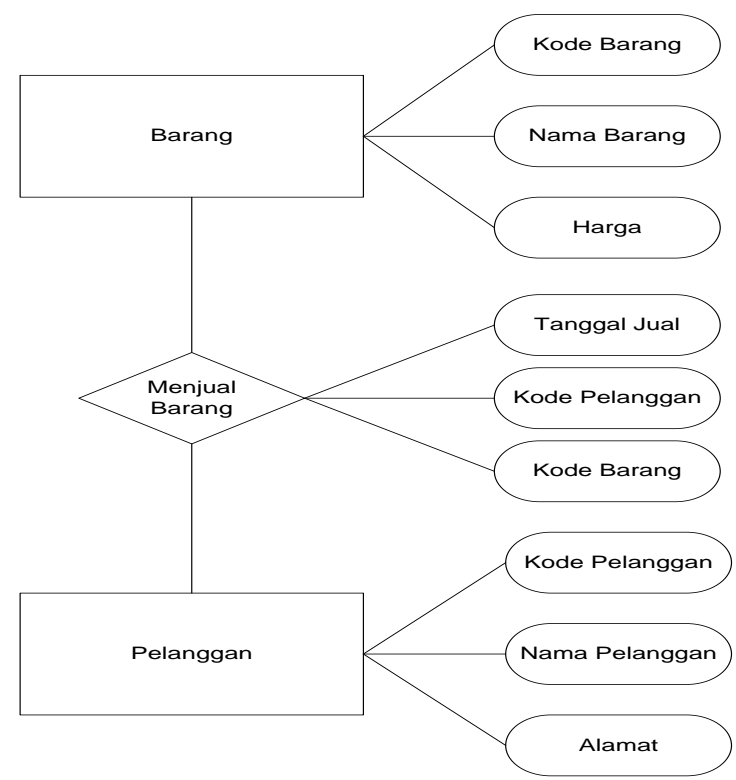

\section{METODE PENELITIAN}

Dalam pengerjaan aplikasi ini menggunakan beberapa metode seperti berikut :

\section{METODE PENGUMPULAN DATA}

\section{a. Wawancara}

Dalam tahapan ini metode yang digunakan yaitu melakukan penelitian dengan mengadakan tanya jawab kepada bagian penjualan yang bertanggung jawab atas segala transaksi penjualan serta gudang yang memiliki tugas atas pengadaan ketersediaan barang serta melakukan wawancara dengan manajer koperasi atau karyawan dalam penyusunan konsep untuk pembuatan aplikasi penjualan.

\section{b. Studi kepustakaan}

Dalam tahapan ini metode yang digunakan yaitu mengumpulkan data maupun informasi dengan membaca literatur atau menelaah buku-buku pedoman yang berkaitan dengan masalah dalam pembuatan aplikasi penjualan.

\section{c. Observasi}

Dalam tahapan ini metode yang digunakan yaitu mengadakan atau melakukan pengumpulan data di Koperasi dengan mengadakan pengamatan langsung (observasi) atas kegiatan atau proses penjualan dan pengelolaan ketersediaan barang terhadap objek yang dituju seperti bagian penjualan, bagian pembelian, konsumen, dan gudang secara langsung. 


\section{Metode Pengembangan Sistem}

Metode yang digunakan dalam pengerjaan aplikasi ini adalah menerapkan tahapan-tahapan model Waterfall atau air terjun, menurut Jogiyanto (2010), tahapan-tahapan model Waterfall adalah model yang dikembangkan untuk pengembangan perangkat lunak, membuat perangkat lunak, model berkembang secara sistematis dari satu tahap ke tahap lain dalam metode seperti air terjun seperti berikut :

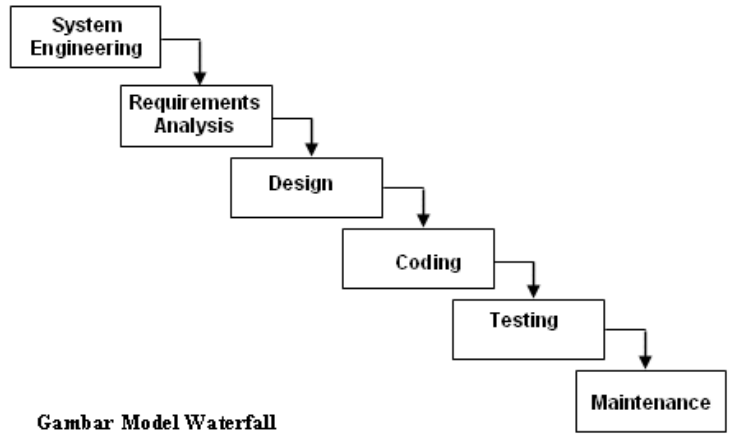

Berdasarkan model pengembangan sistem diatas, penjelasan mengenai tahapan pengembangan sistem sesuai model yang ditentukannya sebagai berikut :

a. System Engineering

Tahap ini adalah mengumpulkan data dan informasi dengan cara wawancara ke bagian penjualan.

b. Requirements Analysis

Tahap ini adalah melakukan analisis permasalahan yang ada di bagian penjualan dan menetepkan aplikasi yang akan di buat.

c. Design

Pada tahap ketiga membuat design sebagai kebutuhan agar dapat diimplementasikan menjadi aplikasi pada tahap selanjutnya.

\section{d. Coding}

Tahap ini mengimplementasikan design kedalam kode-kode program yang terdapat didalam Microsoft Access 2013.

e. Testing

Tahap ini bertujuan untuk menguji aplikasi yang telah dibuat, dengan adanya tahap testing ini akan diketahui apakah aplikasi yang telah dibuat benar atau salah.

\section{f. Maintenance}

Pada tahap ini menangani aplikasi sudah selesai dapat berjalan lancar dan terhindar dari kesalahan atau erorr.

\section{HASIL DAN PEMBAHASAN}

\section{A. TRANSAKSI SIMPANAN YANG BERJALAN}

Berikut hasil yang di dapat dari analisis berjalan pada Koperasi Keluarga Besar PT Dirgantara Indonesia "Wahana Raharja" : 
1. Bagian pengelola penjualan menerima data order dari customer yang akan membeli secara tunai

2. Lalu bagian pengelola penjualan melakukan pencatatan secara manual untuk mengetahui apa saja jenis barang yang telah dibeli oleh customer dan memberikan orderan barang pada customer

3. Setelah proses pencatatan kemudian melakukan pengumpulan data-data penjualan harian

4. Kemudian bagian pengelola penjualan menyerahkan pencatatan harian tersebut pada bagian penjualan

5. Pencatatan yang diterima dari pengelola penjualan, bagian penjualan membuat laporan penjualan harian sebanyak 2 rangkap. Rangkap pertama diarsipkan oleh bagian penjualan dan rangkap kedua diberikan kepada bagian keuangan

6. Bagian keuangan menerima laporan penjualan dan uang atas penjualan tunai

Flowmap Sistem Berjalan Transaksi Pinjaman

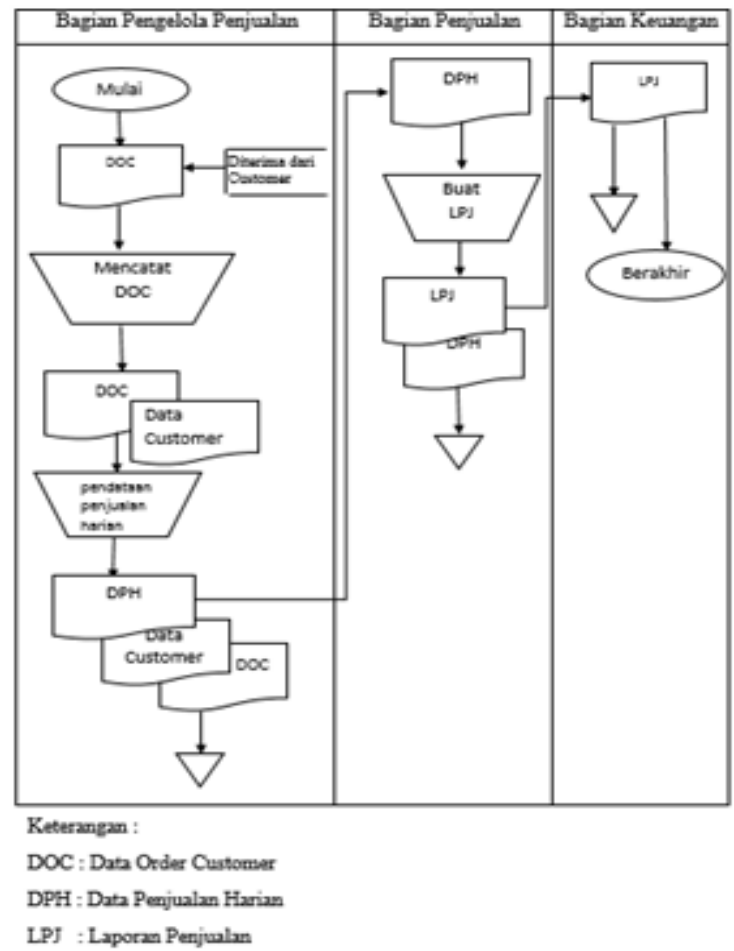

\section{B. TRANSAKSI PINJAMAN USULAN}

Berikut ini gambaran Flowmap Sistem usulan pada Koperasi Keluarga Besar PT Dirgantara Indonesia "Wahana Raharja” :

1. Bagian pengelola penjualan menerima data order dari customer yang akan membeli secara tunai

2. Menginput penjualan jenis barang yang dibeli secara tunai berdasarkan data order customer tersebut dan memberikan orderan barang pada customer

3. Setelah melakukan penginputan kemudian memproses pelaporan dan mencetak laporan dari data-data penjualan harian 
4. Kemudian bagian pengelola penjualan menyerahkan laporan harian tersebut pada bagian penjualan

5. Laporan yang diterima dari pengelola penjualan, bagian penjualan mencocokan data barang dengan data penjualan harian dan di cetak sebanyak 2 rangkap. Rangkap pertama diarsipkan oleh bagian penjualan dan rangkap kedua diberikan kepada bagian keuangan

6. Bagian keuangan menerima laporan penjualan dan uang atas penjualan tunai.

Flowmap Sistem Usulan Transaksi Pinjaman

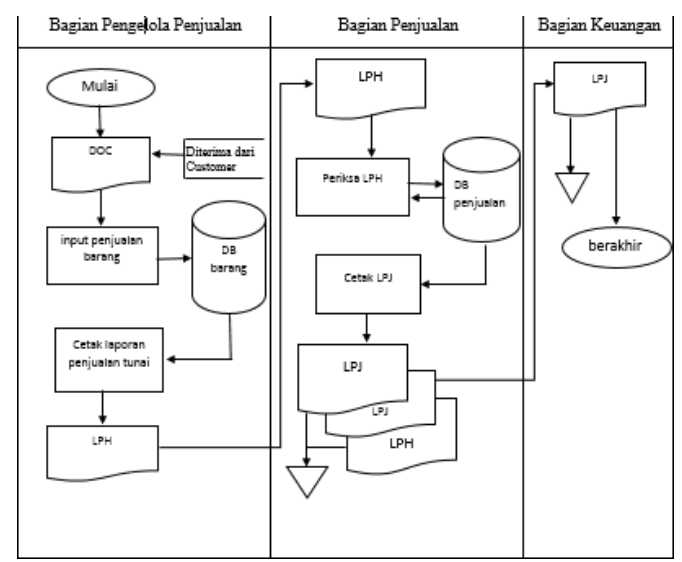

Keterangan :

DOC : Data Order Customer

DB : Data Base

LPH : Laporan Penjualan Harian

LPJ : Laporan Penjualan

C. ANALISIS DOKUMEN MASUKAN DAN KELUARAN

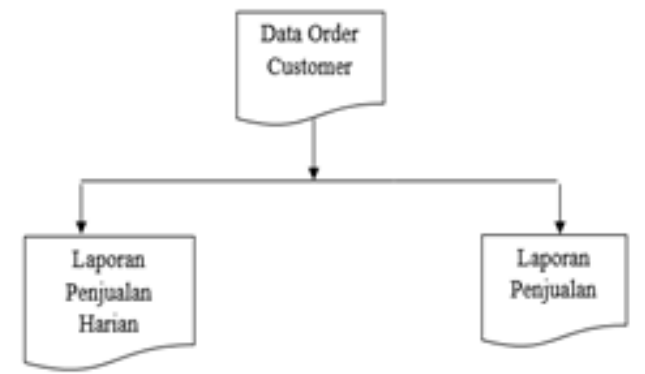

\section{Perancangan Topologi Antarmuka}

Topologi antarmuka menjelaskan skema atau jalur halaman yang menjadi hak akses dari masing-masing user pada aplikasi penjualan tunai harian KKB PT. Dirgantara Indonesia "Wahana Raharja".

Berikut ini adalah topologi yang terdapat pada antarmuka pengelola.

Topologi Antarmuka Pengelola 


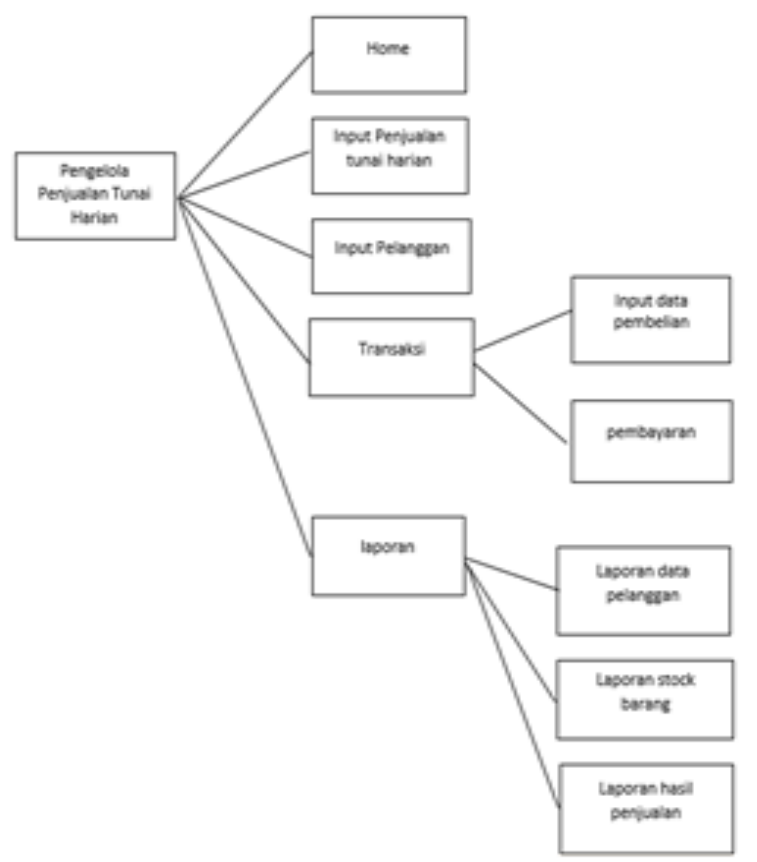

\section{E. Perancangan Dokumen Keluaran}

Menjelaskan dan menggambarkan rancangan dokumen masukan dan/atau dokumen keluaran, seperti Data Order Customer, Laporan Penjualan Harian, dan Laporan Penjualan.

\section{1) Dokumen Masukan}

Data Order Customer

\begin{tabular}{|c|c|}
\hline Nama & : Data Order Customer \\
\hline Sumber & : Customer \\
\hline Fungsi & : Data Order Customer \\
\hline Media & : Kertas \\
\hline Rangkap & $: 1$ \\
\hline Frekuensi & $\begin{aligned} \text { : Pada saat melakukan } \\
\text { transaksi penjualan tunai }\end{aligned}$ \\
\hline Keterangan & $\begin{array}{lr}\text { Data order } & \text { customer } \\
\text { merupakan } & \text { data } \\
\text { permohonan } & \text { perminyaan } \\
\text { kepada } & \text { pengelola } \\
\text { penjualan } & \end{array}$ \\
\hline
\end{tabular}

\section{2) Dokumen Keluaran}

Laporan Penjualan Harian 


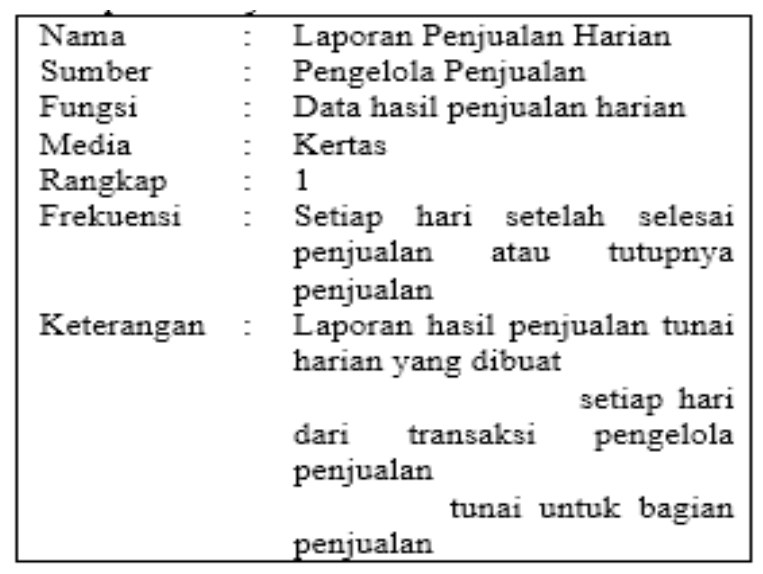

Laporan Penjualan

\begin{tabular}{|ll|}
\hline Nama & $:$ Laporan Penjualan \\
Sumber & $:$ Pengelola Penjualan \\
Fungsi & $:$ Data hasil penjualan \\
Media & $:$ Kertas \\
Rangkap $:$ & 1 \\
Frekuensi $:$ & Setiap hari setelah selesai \\
& penjualan tunai atau tutupnya \\
& penjualan \\
Keterangan & $\begin{array}{l}\text { Laporan hasil penjualan yang } \\
\text { dibuat setiap hari dari laporan } \\
\end{array}$ \\
& penjualan harian \\
\hline
\end{tabular}

F. Perancangan Kebutuhan Perangkat Keras

Dalam pengembangan aplikasi ini dibutuhkan beberapa perangkat keras, baik untuk client maupun server. Untuk spesifikasi server adalah sebagai berikut:

\begin{tabular}{|l|l|l|}
\hline $\begin{array}{c}\text { Perangkat } \\
\text { Keras }\end{array}$ & \multicolumn{1}{|c|}{$\begin{array}{c}\text { Spesifikasi } \\
\text { Minimum }\end{array}$} & Rekomendasi \\
\hline Processor & Intel Core 2 & AMD Brasos \\
\hline Hardisk & $100 \mathrm{~GB}$ & $250 \mathrm{~GB}$ \\
\hline Memory & $512 \mathrm{MB}$ & $2 \mathrm{~GB}$ \\
\hline
\end{tabular}

\section{G. KEBUTUHAN PERANGKAT LUNAK}

Dalam pengembangan aplikasi ini dibutuhkan beberapa perangkat, baik untuk client maupun server. Untuk spesifikasi server adalah sebagai berikut: 
Kebutuhan Perangkat Lunak

\begin{tabular}{|l|l|}
\hline \multicolumn{1}{|c|}{ Jenis Software } & Software yang digunakan \\
\hline Sistem Operasi & Windows XP/Vista/7 \\
\hline Bahasa pemograman & VB.Net \\
\hline Basis Data & Access 2013 \\
\hline Aplikasi Software & Microsoft Access 2013 \\
\hline Web Browser & Mozilla Firefox \\
\hline Image Editting & Adobe Photoshop CS5 \\
\hline Desain Program & Microsoft Word 2013 \\
\hline Documentation & Microsoft Office 2013 \\
\hline
\end{tabular}

\section{H. Perancangan Basis Data}

\section{1) ENTITY RELATIONSHIP DIAGRAM (ERD)}

Entity Reelationship Diagram (ERD) menggambarkan hubungan antar table yang terdapat di database dan dapat mempermudah user dalam memahami setiap relasi antar table yang terdapat dalam database.

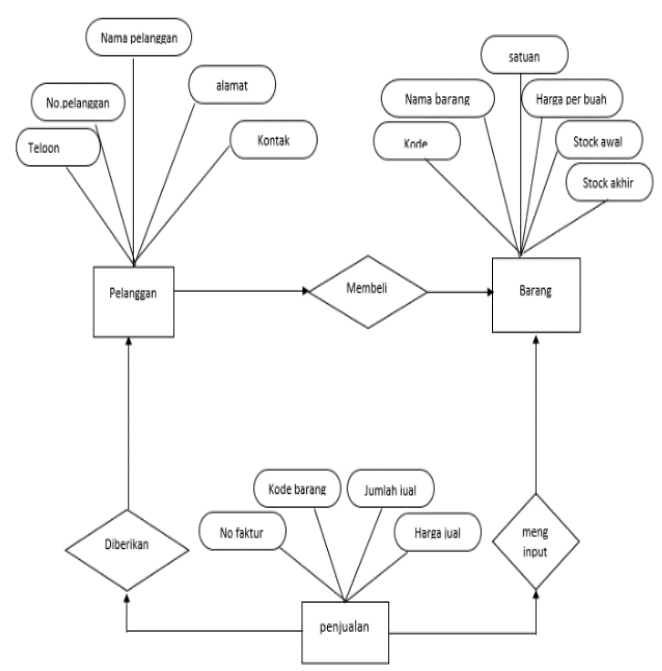

2) Diagram Relasi Antar Tabel

Skema Relasi adalah gambaran yang menunjukan hubungan relasi antar satu table dengan table lainnya yang ada pada database. 


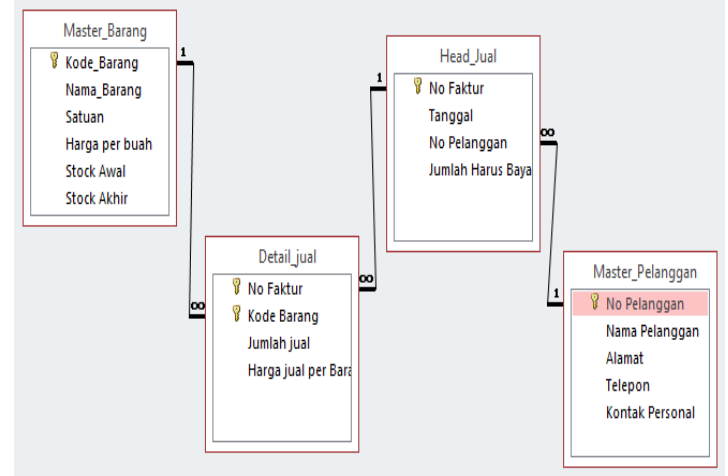

\section{INPLEMENTASI}

1) Halaman Home

\begin{tabular}{|c|c|}
\hline \multicolumn{2}{|c|}{$\begin{array}{l}\text { APLIKASI PENJUALAN TUNAI } \\
\text { HARIAN KEBUTUHAN PANGAN } \\
\text { PADA KKB PT.DIRGANTARA } \\
\text { INDONESIA }\end{array}$} \\
\hline Irpul Perjualan & Dattor Penivion \\
\hline Input Pelongoan & Laporan Dattar Pelangao \\
\hline Ironsoksi Perjualan Tundi & Laporon Stock Penjualan \\
\hline
\end{tabular}

Laporon Hasi Penjudion Tunal

2) Input Data Penjualan Tunai Harian

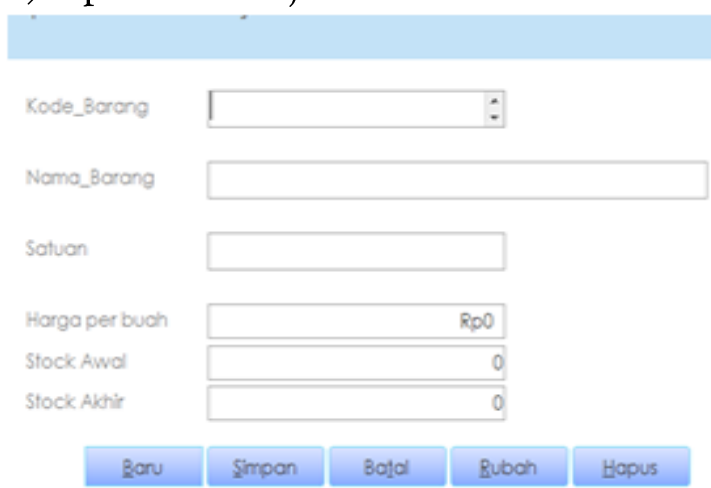

3) INPUT PELANGGAN

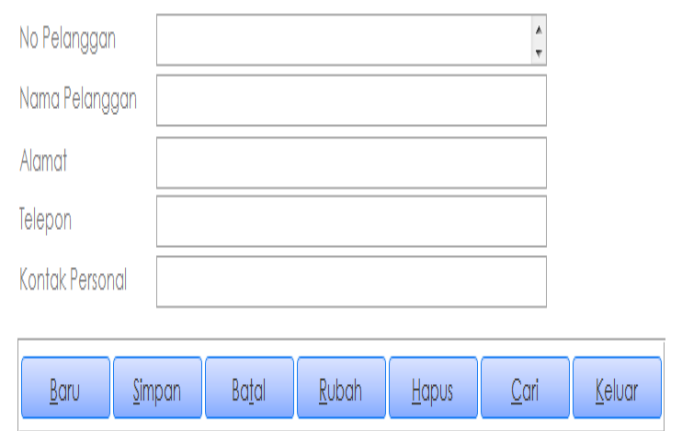


4) Form Transaksi

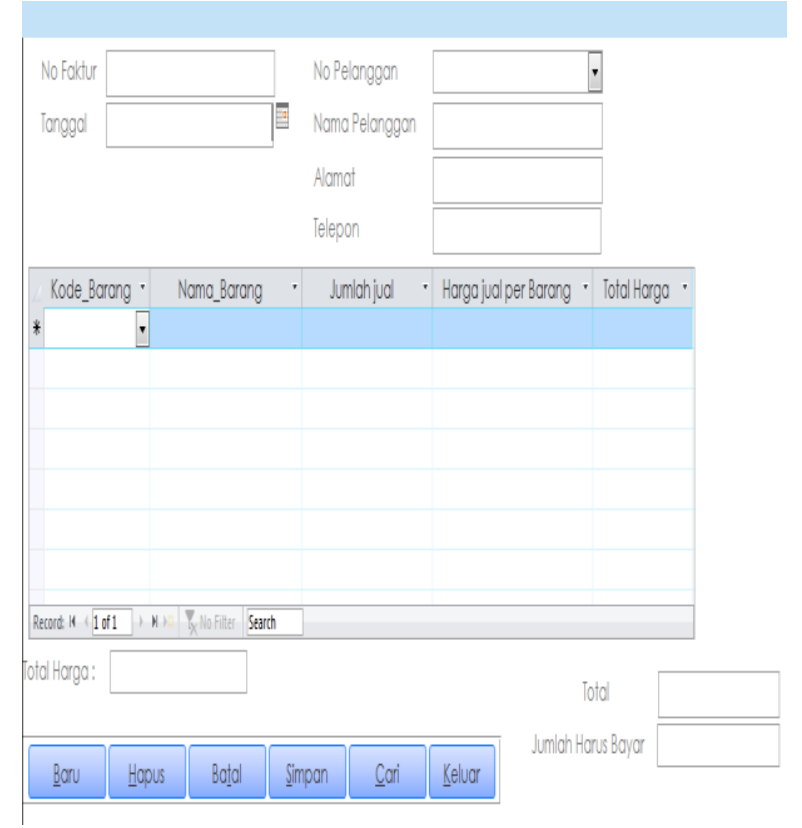

SIMPULAN DAN SARAN

\section{A. Simpulan}

Berdasarkan analis dan pembangunan yang dilakukan, dapat diperoleh kesimpulan sebagai berikut:

1. Dari berbagai prosedur pelayanan transaksi yang ada hingga terbentuknya sistem pencatatan transaksi penjualan masih dengan cara manual. Dengan aplikasi penjualan tunai Microsoft Access ini proses penjualan tunai harian kebutuhan pangan yang ada di Koperasi Keluarga Besar PT Dirgantara Indonesia "Wahana Raharja” dapat dilakukan dengan cepat.

2. Dengan menggunakan aplikasi penjualan tunai Microsoft Access ini pemprosesan data transaksi penjualan tunai harian sampai menghasilkan laporan hasil penjualan dapat dilakukan dengan cepat dan relevan.

3. Aplikasi ini sudah mampu menampilkan output berupa laporan hasil penjualan tunai dan dapat disajikan dengan tepat waktu.

B. Saran

Adapun saran saran yang hendak di sampaikan terhadap pihak pihak yang terkait sehubung dengan hasil analisis sebagai berikut ini:

1. Diharapkan aplikasi penjualan tunai ini dapat diterapkan oleh Koperasi Keluarga Besar PT Dirgantara Indonesia "Wahana Raharja" pada bagian pengelola penjualan untuk proses transaksi penjualan tunai harian sehingga dapat menghasilkan informasi yang cepat dan relevan yang dibutuhkan oleh pihak perusahaan.

2. Adanya pemeliharaan dan perawatan yang rutin terhadap aplikasi penjualan tunai ini sehingga dapat dikembangkan sesuai dengan kebutuhan perusahaan.

3. Penggunaan password pada aplikasi untuk terjaminnya keamanan database sehingga tidak dapat diakses oleh pihak yang tidak terkait. 


\section{DAFTAR PUSTAKA}

Andri Kristanto. 2008. Perancangan Sistem Informasi dan Aplikasinya. Yogyakarta: Gava Media.

A. Diana dan L. S. 2011. Sistem Informasi Akuntansi : Perancangan, Proses, dan Penerapan, Yogyakarta: Andi.

Ardiyos 2008. Sistem Akuntansi Penjualan 1. www.library.upnvj.ac.ad

Basu Swastha. 2008. Manajemen Penjualan. www.belbuk.com/manajemenpenjualan

Chairul Marom. 2008. Sistem Akuntansi Perusahaan dagang. Elib.unikom.ac.id.

Idjan, La. dan Azhar Susanto. 2005. Sistem Informasi Akuntansi 1. Bandung : Lingga Jaya.

James M. Reeve dkk. 2009. Pengantar Akuntansi Adaptasi Indonesia (Principles of Accounting-Indonesian Adaption). Jakarta Selatan: Salemba Empat.

Jogiyanto. 2010. Microsoft Office Access. Elib.unikom.ac.id.

K. dan A. Koniyo. 2007. Tuntunan Praktis Membangun Sistem Informasi Akuntansi dengan Visual Basic dan Microsoft SQL Server, Yogyakarta: Andi.

Krismiaji. (2010). Sistem Informasi Akuntansi. Yogyakarta : UPP STIM YKPN.

Lilis Puspitawati and Sri Dewi Anggadini. 2011. Sistem Informasi Akuntansi. Yogyakarta: Graha Ilmu.

Mulyadi 2008. Sistem Informasi Akuntansi. Jakarta : Salemba Empat.

Sigit Hermawan dan Masyhad. 2006. Akuntansi untuk Perusahaan Jasa dan Dagang. Yogyakarta: Graha Ilmu 